\title{
Seasonal variations of snow chemistry at NEEM, Greenland
}

\author{
Takayuki KURAMOTO, ${ }^{1}$ Kumiko GOTO-AZUMA, ${ }^{1}$ Motohiro HIRABAYASHI, ${ }^{1}$ \\ Takayuki MIYAKE, ${ }^{1}$ Hideaki MOTOYAMA, ${ }^{1}$ Dorthe DAHL-JENSEN, ${ }^{2}$ \\ Jørgen Peder STEFFENSEN ${ }^{2}$ \\ ${ }^{1}$ National Institute of Polar Research, 10-3 Midori-cho, Tachikawa, Tokyo 190-8518, Japan \\ E-mail: kuramoto.takayuki@nipr.ac.jp \\ ${ }^{2}$ Centre for Ice and Climate, Niels Bohr Institute, University of Copenhagen, Juliane Maries Vej 30, \\ DK-2100 Copenhagen, Denmark
}

\begin{abstract}
We conducted a pit study in July 2009 at the NEEM (North Greenland Eemian Ice Drilling) deep ice-coring site in northwest Greenland. To examine the seasonal variations of snow chemistry and characteristics of the drill site, we collected snow/firn samples from the wall of a $2 \mathrm{~m}$ deep pit at intervals of $0.03 \mathrm{~m}$ and analyzed them for electric conductivity, $\mathrm{pH}, \mathrm{Cl}^{-}, \mathrm{NO}_{3}{ }^{-}, \mathrm{SO}_{4}{ }^{2-}, \mathrm{CH}_{3} \mathrm{SO}_{3}{ }^{-}(\mathrm{MSA}), \mathrm{Na}^{+}, \mathrm{K}^{+}$, $\mathrm{Mg}^{2+}, \mathrm{Ca}^{2+}$ and stable isotopes of water $\left(\delta^{18} \mathrm{O}\right.$ and $\left.\delta \mathrm{D}\right)$. Pronounced seasonal variations in the stable isotopes of water were observed, which indicated that the snow had accumulated regularly during the past 4 years. Concentrations of $\mathrm{Na}^{+}, \mathrm{Cl}^{-}$and $\mathrm{Mg}^{2+}$, which largely originate from sea salt, peaked in winter to early spring, while $\mathrm{Ca}^{2+}$, which mainly originates from mineral dust, peaked in late winter to spring, slightly later than $\mathrm{Na}^{+}, \mathrm{Cl}^{-}$and $\mathrm{Mg}^{2+}$. Concentrations of $\mathrm{NO}_{3}{ }^{-}$showed double peaks, one in summer and the other in winter to spring, whereas those of $\mathrm{SO}_{4}{ }^{2-}$ peaked in winter to spring. The winter-to-spring concentrations of $\mathrm{NO}_{3}{ }^{-}$and $\mathrm{SO}_{4}{ }^{2-}$ seem to have been strongly influenced by anthropogenic inputs. Concentrations of MSA showed double peaks, one in spring and the other in late summer to autumn. Our study confirms that the NEEM deep ice core can be absolutely dated to a certain depth by counting annual layers, using the seasonal variations of stable isotopes of water and those of ions. We calculated the annual surface mass balance for the years 2006-08. The mean annual balance was $176 \mathrm{~mm}$ w.e., and the balances for winter-to-summer and summer-to-winter halves of the year were 98 and $78 \mathrm{~mm}$, respectively. Snow deposition during the winter-to-summer half of the year was greater than that during the summer-to-winter half by $\mathbf{1 0 - 2 0 ~} \mathrm{mm}$ for all three years covered by this study.
\end{abstract}

\section{INTRODUCTION}

Deep ice cores from Greenland and Antarctica have provided us with excellent records of the late Quaternary climate and environment (e.g. Dansgaard and others, 1982; GRIP Members, 1993; Grootes and others, 1993; EPICA Community Members, 2004, 2006; NorthGRIP Members, 2004). Although ice-core records from Antarctica cover the past eight glacial cycles (EPICA Community Members, 2004), those from Greenland only date back to the middle of the Last Interglacial, which is known as the Eemian period (NorthGRIP Members, 2004). Since the Eemian (130-115 ka BP) was substantially warmer than today (NorthGRIP Members, 2004), having the full record of the Eemian would enable us to study in detail climatic and environmental changes in a warmer climate, which are crucial for predicting future global changes.

To reconstruct the climate and environment during the Eemian, the NEEM (North Greenland Eemian Ice Drilling) project has been initiated. The new drill site NEEM was selected at $77^{\circ} 26^{\prime} 55^{\prime \prime} \mathrm{N}, 51^{\circ} 03^{\prime} 20^{\prime \prime} \mathrm{W}$ (2445 ma.s.I.) in northwest Greenland (Fig. 1). Based on radio-echo sounding and ice-flow modeling, Buchardt and Dahl-Jensen (2008) have shown that a full record of the Eemian can be obtained at this site $\sim 100 \mathrm{~m}$ above bedrock.

The chemical components in ice cores provide valuable information on past atmospheric conditions and changes in aerosol sources (e.g. Legrand and Mayewski, 1997; Petit and others, 1999). In Greenland, many of the chemical components and stable isotopes of water show clear seasonal variations (e.g. Finkel and others, 1986; Steffensen, 1988; Beer and others, 1991; Whitlow and others, 1992; Candelone and others, 1996). Patterns of these seasonal variations are useful tools for investigating the sources of aerosols, atmospheric circulation and deposition processes onto the ice sheet. Seasonal variations back to $60 \mathrm{ka}$ BP have been used for ice-core dating in Greenland, as the annual accumulation rate is sufficiently high to allow for sub-annual sampling (Svensson and others, 2008).

Under the ongoing NEEM project, the ice core will be absolutely dated further back in the Eemian using the annuallayer counting method. To fully interpret the chemistry data obtained from the NEEM deep ice core and for accurate absolute dating, it is necessary to assess the seasonal variations of the chemical components in the present-day snow. It is also a prerequisite for understanding the characteristics of the NEEM site, including the surface mass balance and melt effects (if any). In this paper, we present the results of a pit study conducted at NEEM in July 2009 to address these issues.

\section{METHODS}

We conducted a snow/firn pit study on 5 July 2009 at a site located $2600 \mathrm{~m}$ east $\left(77^{\circ} 26^{\prime} 49^{\prime \prime} \mathrm{N}, 50^{\circ} 56^{\prime} 47^{\prime \prime} \mathrm{W}\right)$ of the NEEM deep drilling site (Fig. 1). As the prevailing wind direction in this area is south, the study site was selected to be least influenced by the NEEM camp. A $\sim 2 \mathrm{~m}$ deep pit was dug from the surface. Snow densities and temperatures were 




Fig. 1. Location map of NEEM, Greenland.

measured every $0.03 \mathrm{~m}$. A stainless-steel snow sampler with a height of $0.03 \mathrm{~m}$ was used for the density measurements. After these measurements, samples for chemical analyses were collected at $0.03 \mathrm{~m}$ intervals with a pre-cleaned stainless-steel sampler and were then placed into individual Whirl-Pak ${ }^{\circledR}$ sample bags (Nasco). The samples were melted in the bags and transferred to pre-cleaned polypropylene bottles in the NEEM camp. The samples were then refrozen and transported to the National Institute of Polar Research (NIPR) in Japan.
At NIPR, the samples were melted again, then $\mathrm{pH}_{\text {, }}$ electric conductivity and ions $\left(\mathrm{Cl}^{-}, \mathrm{NO}_{3}{ }^{-}, \mathrm{SO}_{4}{ }^{2-}, \mathrm{CH}_{3} \mathrm{SO}_{3}{ }^{-}\right.$ (MSA hereafter), $\mathrm{Na}^{+}, \mathrm{K}^{+}, \mathrm{Mg}^{2+}$ and $\mathrm{Ca}^{2+}$ ) were analyzed in a class 10000 clean room with a pH meter (TOADKK: MM60R with a pH sensor GST-5720C), a conductivity meter (TOADKK: MM-60R with an order-made conductivity sensor CT-87101B(S)) and ion chromatographs (Dionex: DX-500), respectively. Dionex AS11-HC and CS14 columns were used for anion and cation analyses, respectively. The analytical precision was better than $2 \%$ at 1 ppb level for all the ions. Stable isotopes of water $\left(\delta^{18} \mathrm{O}, \delta \mathrm{D}\right)$ were analyzed with an isotope mass spectrometer (Thermo: Delta plus) by an equilibrium method in a laboratory next to the clean room. The precision $(1 \sigma)$ of determination was $0.05 \%$ for $\delta^{18} \mathrm{O}$ and $0.5 \%$ for $\delta \mathrm{D}$ (Uemura and others, 2004).

\section{RESULTS AND DISCUSSION}

\section{Seasonal variations of stable isotopes, density and ion concentrations}

Figure 2 shows the vertical profiles of the stable isotopes of water $\left(\delta^{18} \mathrm{O}, \delta \mathrm{D}\right)$ and deuterium-excess (d-excess; $\mathrm{d}=\delta \mathrm{D}-8 \delta^{18} \mathrm{O}$ ) obtained from the pit. The $\delta^{18} \mathrm{O}$ and $\delta \mathrm{D}$ varied synchronously and showed distinct seasonal variations, with the most recent peak occurring near the snow surface of 5 July 2009. Steffensen (1985) reported that the $\delta^{18} \mathrm{O}$ values of snow vary in parallel with the temperatures at Dye 3, Greenland. A similar seasonality in $\delta^{18} \mathrm{O}$ has also been reported at other Greenland sites (e.g. Finkel and others, 1986; Beer and others, 1991). Therefore, we can reasonably assume that the layers with $\delta^{18} \mathrm{O}$ and $\delta \mathrm{D}$ maxima and minima were summer and winter layers, respectively. We dated the pit using the seasonal variation of $\delta^{18} \mathrm{O}$ and $\delta$ D. The $2 \mathrm{~m}$ deep pit contained snow deposited over a 4 year period. The seasonal variation of d-excess, which depends on the sea surface temperature and evaporation processes of sea water in the vapor source region (e.g. Uemura, 2007), differed from that of $\delta^{18} \mathrm{O}$ and $\delta \mathrm{D}$, as it



Fig. 2. Vertical profiles of stable isotopes of water $\left(\delta^{18} \mathrm{O}\right.$ and $\left.\delta \mathrm{D}\right)$ and $\mathrm{d}$-excess. Summer and winter were defined from maximum and minimum values of $\delta^{18} \mathrm{O}$ and $\delta \mathrm{D}$, respectively. 


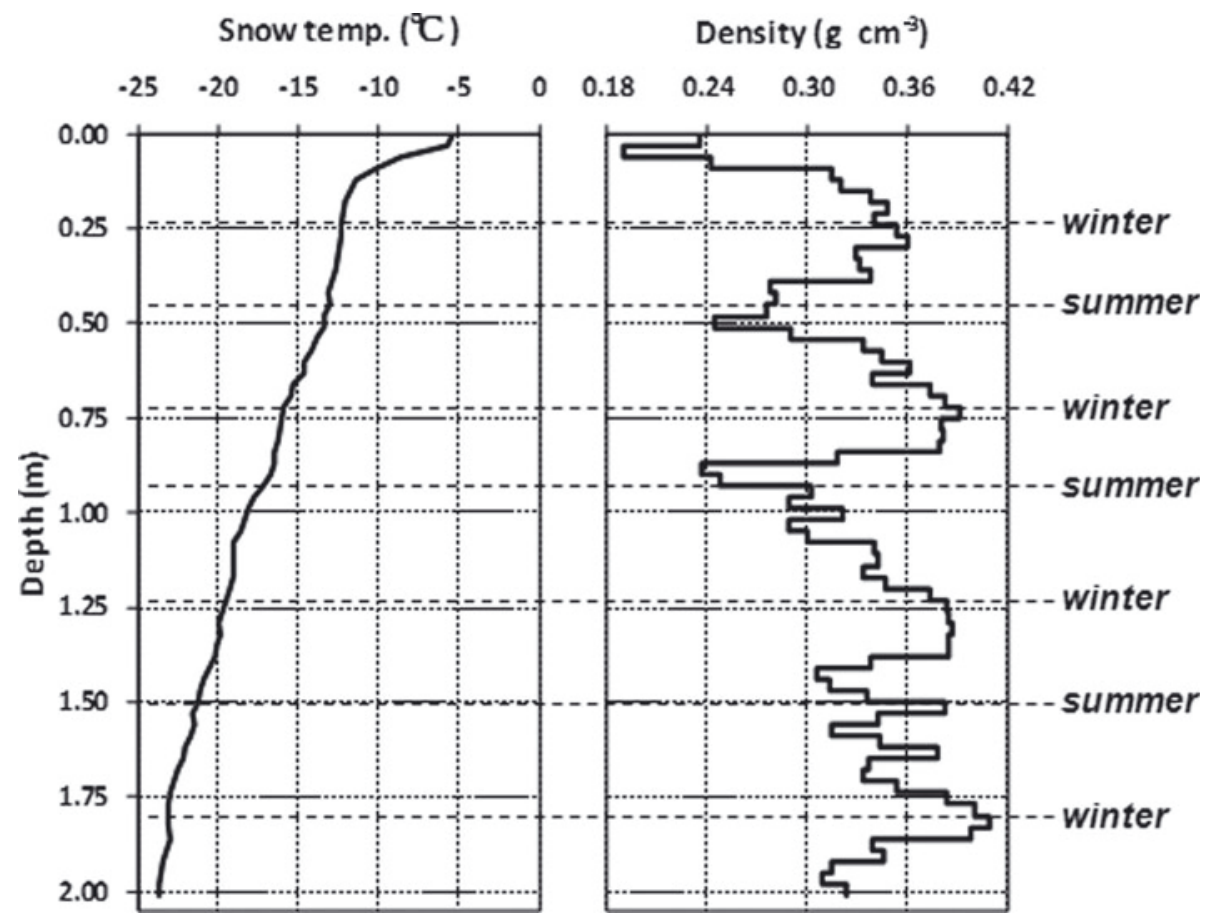

Fig. 3. Vertical profiles of snow temperature and density.

showed maxima in autumn and minima from spring to early summer. The seasonal variability of d-excess observed at NEEM is similar to that reported at other Greenland icecoring sites (Johnsen and others, 1989).

The snow density also showed seasonal variation, which is superimposed on the general trend of increasing density with depth (Fig. 3). Low-density layers were observed at depths of approximately 0.05, 0.50, 0.90, 1.40 and $2.00 \mathrm{~m}$. A comparison with the stable-isotope profiles (Fig. 2) indicates that these were summer layers. The seasonality of snow density at NEEM was similar to that observed at Summit, Greenland (Albert and Shultz, 2002), which was caused by a wind-pack effect resulting in a higher density of snow in winter. Although the wind speed at NEEM appears to be greater in winter than in other seasons, which may account for the increased snow density, this speculation needs to be confirmed using the data from the automatic weather station that was installed at NEEM during the 2009 season. The snow temperature (Fig. 3) continued to decrease from the surface to the bottom of the pit $\left(-23.7^{\circ} \mathrm{C}\right.$ at $2.01 \mathrm{~m}$ depth). As the visual stratigraphy of the pit showed little horizontal variability, we assume that snow and ion depositions were not seriously disturbed by wind scouring.

We found thin ice layers with thickness of $\sim 1 \mathrm{~mm}$ or less in the pit, at depths of approximately $0.11,0.18$ and $0.23 \mathrm{~m}$, which were formed by minor surface snowmelt during the summer months at NEEM. The occurrence of slight summer surface melting did not have a noticeable impact on the profiles of stable isotopes and ions, since both showed regular variations (Figs 2 and 4 ).

The vertical profiles of $\mathrm{pH}$, electric conductivity and concentrations of ions $\mathrm{Cl}^{-}, \mathrm{NO}_{3}{ }^{-}, \mathrm{SO}_{4}{ }^{2-}, \mathrm{MSA}, \mathrm{Na}^{+}, \mathrm{K}^{+}$, $\mathrm{Mg}^{2+}$ and $\mathrm{Ca}^{2+}$ ) are shown in Figure 4. Non-sea-salt (nss) components of $\mathrm{Cl}^{-}, \mathrm{SO}_{4}{ }^{2-}, \mathrm{K}^{+}, \mathrm{Mg}^{2+}$ and $\mathrm{Ca}^{2+}$ were calculated using sea-water ratios of these ions with respect to $\mathrm{Na}^{+}$, assuming that $\mathrm{Na}^{+}$is solely of sea-salt origin, and are plotted in Figure 4. For instance, concentration of $\mathrm{nssCl}^{-}$,
[nssCl- ${ }^{-}$, was calculated with the following equation:

$$
\left[\mathrm{nssCl}^{-}\right]=\left[\mathrm{Cl}^{-}\right]-\left(\mathrm{Cl}^{-} / \mathrm{Na}^{+}\right)_{\text {sea }} \times\left[\mathrm{Na}^{+}\right],
$$

where $\left(\mathrm{Cl}^{-} / \mathrm{Na}^{+}\right)_{\text {sea }}$ is the equivalent concentration ratio of $\mathrm{Cl}^{-} / \mathrm{Na}^{+}$in the sea water, which is 1.17 . Similarly, concentrations of $\mathrm{nssSO}_{4}{ }^{2-}, \mathrm{nssK}^{+}, \mathrm{nssMg}^{2+}$ and $\mathrm{nssCa}^{2+}$ were calculated using sea-water ratios 0.12, 0.021, 0.23 and 0.044 , respectively. On average, non-sea-salt fractions of $\mathrm{Cl}^{-}, \mathrm{SO}_{4}{ }^{2-}, \mathrm{K}^{+}, \mathrm{Mg}^{2+}$ and $\mathrm{Ca}^{2+}$ were $26 \%, 96 \%, 66 \%, 47 \%$ and $92 \%$, respectively.

Concentrations of $\mathrm{Na}^{+}$and $\mathrm{Cl}^{-}$showed very similar profiles, with pronounced seasonal variations. Both ions peaked in winter to early spring. Concentrations of $\mathrm{Mg}^{2+}$ also peaked in winter to early spring, while those of $\mathrm{Ca}^{2+}$ peaked in late winter to spring, slightly later than $\mathrm{Na}^{+}, \mathrm{Cl}^{-}$ and $\mathrm{Mg}^{2+}$. The concentrations of $\mathrm{K}^{+}$showed a peak in winter to spring and possibly a secondary peak in summer. Concentrations of $\mathrm{NO}_{3}{ }^{-}$showed double peaks, one in summer and the other in winter to spring, whereas those of $\mathrm{SO}_{4}{ }^{2-}$ peaked in winter to spring. Concentrations of MSA seem to show double peaks, one in spring and the other in late summer to autumn. Seasonal variations of $\mathrm{pH}$ and electric conductivity were not very clear in the present-day snow at NEEM.

The winter-to-early-spring peak observed for $\mathrm{Na}^{+}$and $\mathrm{Cl}^{-}$ is in agreement with previous studies carried out on the Greenland ice sheet (Steffensen, 1988; Whitlow and others, 1992; Candelone and others, 1996; Dibb and others, 2007). In order to examine seasonal changes of $\mathrm{Na}^{+}$and $\mathrm{Cl}^{-}$ sources, we computed $\mathrm{Cl}^{-} / \mathrm{Na}^{+}$ratios (Fig. 5). The ratios showed clear seasonal variations, with peaks occurring in summer when $\mathrm{Cl}^{-}$concentrations were higher than $\mathrm{Na}^{+}$ concentrations with respect to the sea-water ratio. The $\mathrm{Cl}^{-} /$ $\mathrm{Na}^{+}$peaks can thus be used as an indicator of summer layers at NEEM. The high $\mathrm{Cl}^{-} / \mathrm{Na}^{+}$ratios together with elevated nssCl ${ }^{-}$concentrations (Fig. 4) in summer suggest that $\mathrm{Cl}^{-}$ ions in summer Greenland snow were supplied from sources 

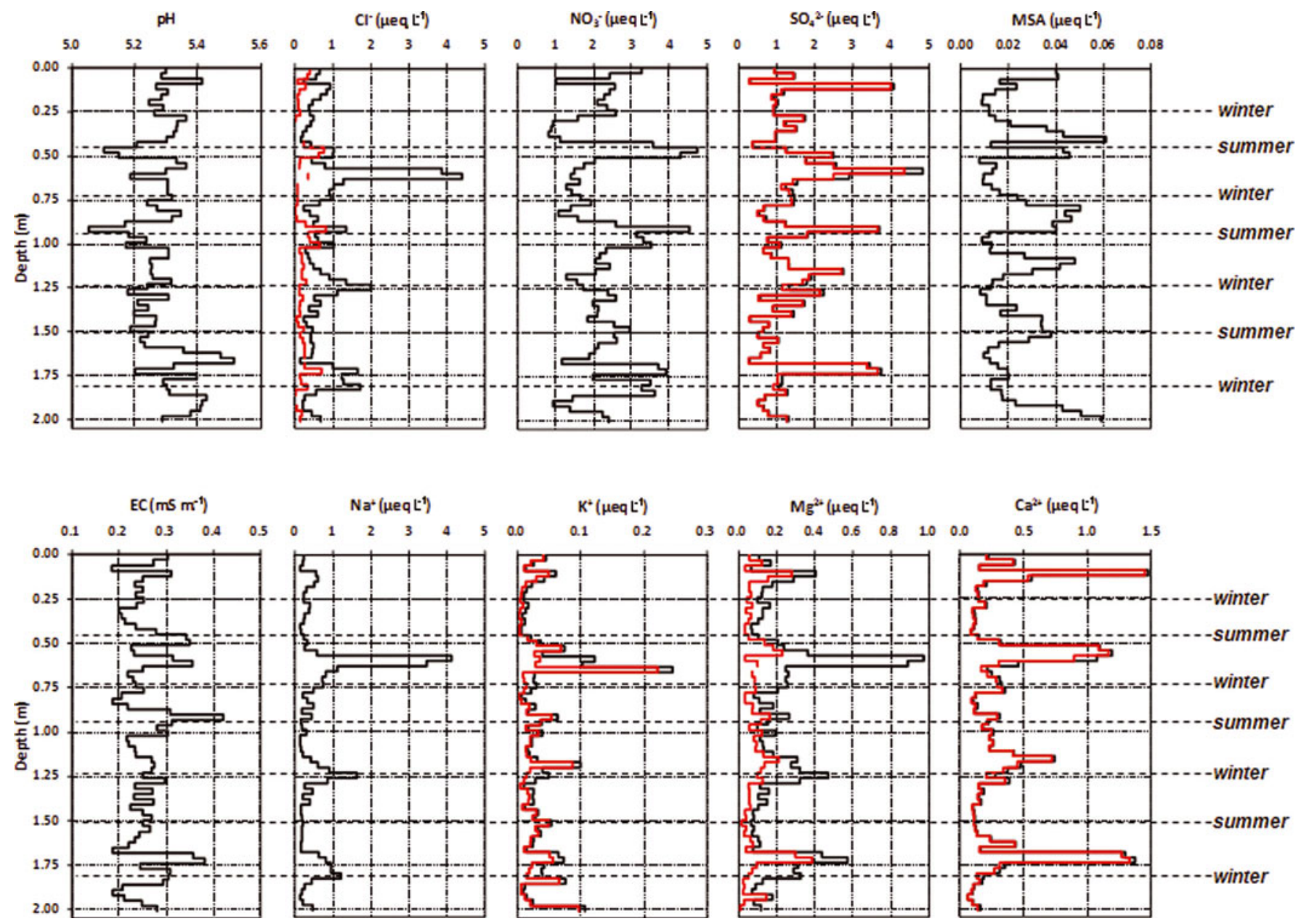

Fig. 4. Vertical profiles of electric conductivity, $\mathrm{pH}$, and ion concentrations. Black and red curves indicate total concentrations and non-seasalt (nss) fractions, respectively.

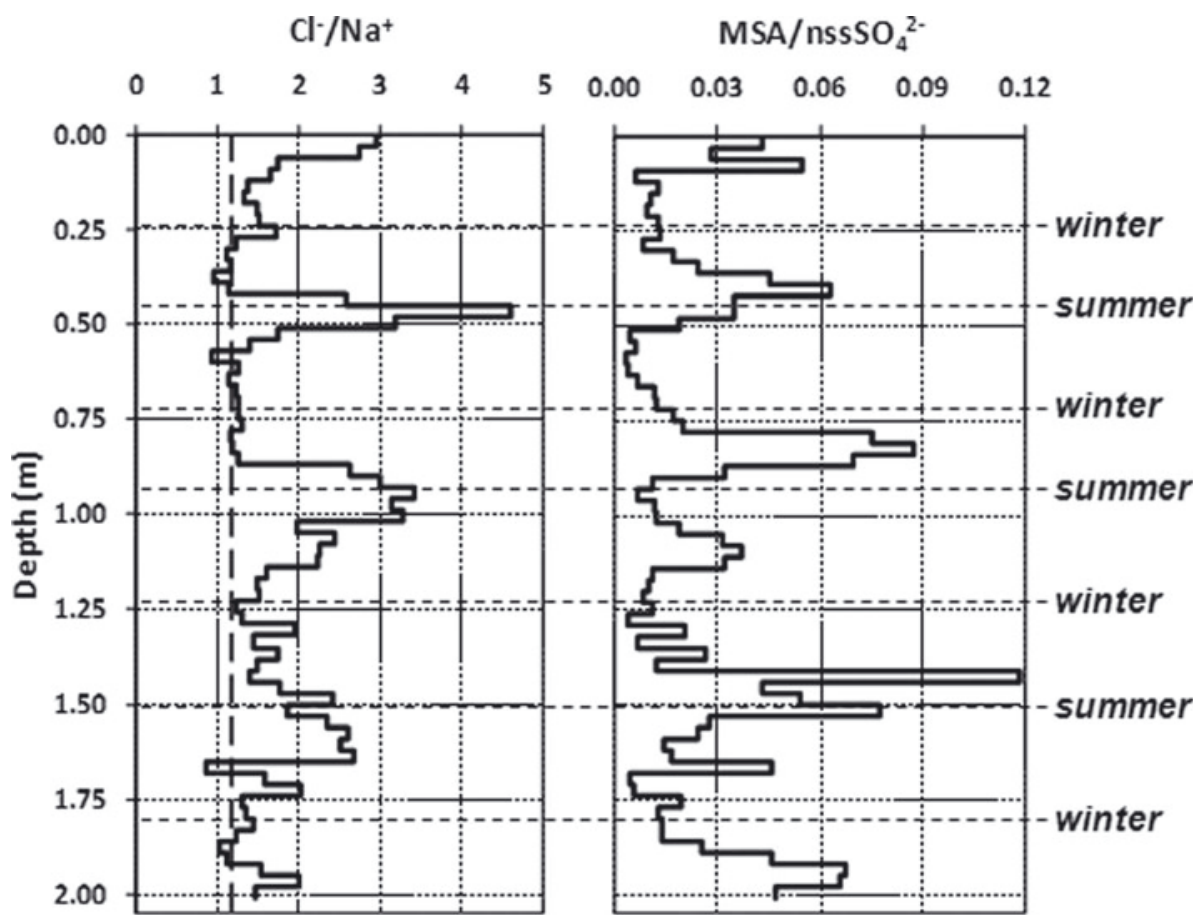

Fig. 5. Vertical profiles of $\mathrm{Cl}^{-} / \mathrm{Na}^{+}$and $\mathrm{MSA} / \mathrm{nsSSO}_{4}{ }^{2-}$. The dashed line represents the $\mathrm{Cl}^{-} / \mathrm{Na}^{+}$ratio in sea water (1.17). 
other than sea-salt aerosols, such as gaseous $\mathrm{HCl}$ due to seasalt dechlorination (e.g. Legrand and Delmas, 1988; Legrand and others, 2002). On the other hand, the $\mathrm{Cl}^{-} / \mathrm{Na}^{+}$ratios in winter to early spring were very close to that of sea water, suggesting that in winter to early spring, $\mathrm{Na}^{+}$and $\mathrm{Cl}^{-}$mainly originated from sea-salt aerosols.

The seasonal variation of $\mathrm{Ca}^{2+}$ concentrations was similar to that observed by Dibb and others (2007), who collected and analyzed surface snow every day for 3 years at Summit, Greenland. They reported that $\mathrm{Ca}^{2+}$, which mainly originates from dust, showed a strong peak in April. As the seasalt fraction of $\mathrm{Ca}^{2+}$ is small (Fig. 4), the major source of $\mathrm{Ca}^{2+}$ at the NEEM site would be mineral dust. Dust layers have been observed in late-winter-to-spring snow layers in Yukon, Canada (Goto-Azuma and others, 2006), and over wide areas of the Greenland ice sheet (e.g. Steffensen, 1988; Whitlow and others, 1992; Mosher and others, 1993; Drab and others, 2002). Although these sites are distant from Asia, their major sources of dust were attributed to those in Asia. Therefore, $\mathrm{nssCa}^{2+} /$ dust transported to the NEEM site in spring would have also likely originated from Asian sources. Apportionment of $\mathrm{Mg}^{2+}$ by calculation of sea-salt and nss components (Fig. 4) suggests that the rising leg of the $\mathrm{Mg}^{2+}$ peak in winter to early spring is of sea-salt origin and that the later part of the peak is due to the influx of mineral dust.

The summer $\mathrm{NO}_{3}{ }^{-}$peak (Fig. 4) was consistent with previous studies carried out on the Greenland ice sheet (Steffensen, 1988; Beer and others, 1991; Whitlow and others, 1992; Fischer and others, 1998; Motoyama and others, 2001; Dibb and others, 2007). The winter-to-earlyspring peak in the $\mathrm{NO}_{3}{ }^{-}$concentration observed at NEEM was also observed in modern snow at Summit, Greenland (Whitlow and others, 1992; Dibb and others, 2007), and on Agassiz Ice Cap in the Canadian High Arctic (Goto-Azuma and others, 1997), which was attributed to anthropogenic sources. Though Finkel and others (1986) found a major single summer peak in $\mathrm{NO}_{3}{ }^{-}$concentrations both in pre- and post-industrial south Greenland snow, they reported an increase of $\mathrm{NO}_{3}{ }^{-}$concentrations in late winter/early spring since the 1950s due to anthropogenic inputs. To determine the sources of $\mathrm{NO}_{3}{ }^{-}$, Hastings and others (2004) analyzed nitrogen and oxygen isotopes of $\mathrm{NO}_{3}{ }^{-}$in snow at Summit, Greenland. Based on seasonal variations of $\delta^{15} \mathrm{~N}$, they reported that the predominant source of $\mathrm{NO}_{3}{ }^{-}$in summer was natural $\mathrm{NO}_{x}$ produced by biomass burning, biogenic soil emissions and lightning, whereas that in winter was anthropogenic $\mathrm{NO}_{x}$ from fossil fuel combustion. Since the seasonal variation of $\mathrm{NO}_{3}{ }^{-}$at NEEM resembled those documented at other sites in the Arctic, we suggest that the summer and winter-to-early-spring peaks of $\mathrm{NO}_{3}{ }^{-}$at NEEM are also mainly of natural and anthropogenic origin, respectively. For confirmation, further studies using isotopes, etc., are necessary at NEEM.

The seasonal variations of MSA in the snow at NEEM coincided with those in the air and snow at Dye 3 and Summit, Greenland ( $\mathrm{Li}$ and others, 1993b; Jaffrezo and others, 1994), and with those in the air at Alert in the Canadian High Arctic ( $\mathrm{Li}$ and others, 1993a). MSA is an oxidization product from dimethylsulfide (DMS), which is mainly produced by marine phytoplankton (e.g. Legrand and Mayewski, 1997). The spring peak in MSA may have been caused by enhanced photochemical activity after the polar sunrise, when solar radiation becomes available to oxidize the winter reservoir of DMS ( $\mathrm{Li}$ and others, 1993b).
Alternatively, it could have been caused by long-range transport from lower-latitude oceans (Li and others, 1993b). The MSA peak in late summer to autumn, when sea ice around Greenland has retreated, could have been produced by regional DMS emissions.

The potential sources of $\mathrm{SO}_{4}{ }^{2-}$ include sea salt, volcanic eruptions, $\mathrm{SO}_{2}$ produced by fossil fuel combustion, dust, and DMS emissions produced by marine phytoplankton (Legrand and others, 1995; Legrand, 1997; Legrand and Mayewski, 1997). As can be seen in Figure 4, sea salt is only a minor component of $\mathrm{SO}_{4}{ }^{2-}$ at the high-elevation site NEEM. Large-magnitude volcanic eruptions produce spikes in $\mathrm{SO}_{4}{ }^{2-}$ concentration (e.g. Legrand and Mayewski,

1997). They are, however, sporadic and do not make a substantial contribution to the $\mathrm{SO}_{4}{ }^{2-}$ budget in years without large explosive volcanism. The $\mathrm{SO}_{4}{ }^{2-}$ peak in winter to spring (Fig. 4) has also been documented at other ice-sheet sites in north, central and south Greenland (Finkel and others, 1986; Beer and others, 1991; Whitlow and others, 1992; Jaffrezo and others, 1994; Fischer and others, 1998; Bigler and others, 2002; Dibb and others, 2007) and at an ice-cap site in the Canadian High Arctic (Goto-Azuma and others, 1997). A similar seasonal variation was seen in $\mathrm{nsSO}_{4}{ }^{2-}$ in the air in Greenland and the Canadian High Arctic (Barrie and Barrie, 1990; Jaffrezo and others, 1994; Norman and others, 1999). Studies in central and south Greenland and in the Canadian High Arctic suggest that the winter-to-early-spring peak was due to the inflow of anthropogenic air pollutants. Similarly, the winter-to-earlyspring peak of $\mathrm{SO}_{4}{ }^{2-}$ at NEEM may also be attributed to air pollutants produced by fossil fuel combustion. On the other hand, Bigler and others (2002) reported that a single winter-to-early-spring peak has been observed both in preindustrial and modern snow in north Greenland, though a small shift in the seasonality between them was seen. This would imply that in north Greenland both natural and anthropogenic $\mathrm{SO}_{4}{ }^{2-}$ peak in winter to early spring, in contrast to central and south Greenland and to the Canadian High Arctic, where natural $\mathrm{SO}_{4}{ }^{2-}$ peaks in summer (Finkel and others, 1986; Whitlow and others, 1992; Goto-Azuma and others, 1997; Dibb and others, 2007). If this is the case, the winter-to-early-spring $\mathrm{SO}_{4}{ }^{2-}$ peak in the modern snow at NEEM could also have both anthropogenic and natural sources.

We now discuss the contributions of mineral dust and oxidation products of DMS to the $\mathrm{SO}_{4}{ }^{2-}$ budget at NEEM. The spring maxima of $\mathrm{nsSSO}_{4}{ }^{2-}$ were seen at depths around $0.11,0.57,1.14$ and $1.71 \mathrm{~m}$ (Fig. 4), where $\mathrm{nssCa}^{2+}$ also displayed the spring maxima, indicating that $\mathrm{CaSO}_{4}$ is one of the major sources of both $\mathrm{SO}_{4}{ }^{2-}$ and $\mathrm{Ca}^{2+}$ in spring. Earlier studies showed that $\mathrm{SO}_{4}{ }^{2-}$ and $\mathrm{Ca}^{2+}$ peaks in spring were associated with episodes of increased atmospheric dust (e.g. Barbante and others, 2003). The reaction of $\mathrm{CaCO}_{3}$ from Asian dust sources with $\mathrm{H}_{2} \mathrm{SO}_{4}$ (e.g. Legrand and Mayewski, 1997) during the transport to northwest Greenland may have largely contributed to the spring maximum of $\mathrm{SO}_{4}{ }^{2-}$ and $\mathrm{Ca}^{2+}$ concentrations. Nevertheless, $\mathrm{nssSO}_{4}{ }^{2-} / \mathrm{nssCa}^{2+}$ ratios at the spring maxima were larger than the stochastic ratio of $\mathrm{CaSO}_{4}$, which suggests that other nssSO ${ }_{4}{ }^{2-}$ sources are also important. Anthropogenic input of $\mathrm{nssSO}_{4}{ }^{2-}$ would be an important source particularly during winter and early spring, as was the case for Summit and Dye 3, Greenland (Finkel and others, 1986; Mann and others, 2008), and for Alert, a Canadian High Arctic site (Nriagu and others, 1991). 
Table 1. Annual surface mass balances from $2005 / 06$ winter to $2008 / 09$ winter. Concentrations of $\mathrm{H}^{+}$were calculated from $\mathrm{pH}$ values.

\begin{tabular}{|c|c|c|c|c|c|c|c|c|c|c|}
\hline & $\begin{array}{l}\mathrm{H}_{2} \mathrm{O} \\
\mathrm{mm}\end{array}$ & $\begin{array}{c}\mathrm{H}^{+} \\
\mu \mathrm{Eq} \mathrm{m}^{-2}\end{array}$ & $\begin{array}{c}\mathrm{Na}^{+} \\
\mu \mathrm{Eq} \mathrm{m}^{-2}\end{array}$ & $\begin{array}{c}\mathrm{K}^{+} \\
\mu \mathrm{Eq} \mathrm{m}^{-2}\end{array}$ & $\begin{array}{c}\mathrm{Mg}^{2+} \\
\mu \mathrm{Eqm}^{-2}\end{array}$ & $\begin{array}{c}\mathrm{Ca}^{2+} \\
\mu \mathrm{Eqm}^{-2}\end{array}$ & $\begin{array}{c}\mathrm{Cl}^{-} \\
\mu \mathrm{Eqm}^{-2}\end{array}$ & $\begin{array}{c}\mathrm{SO}_{4}{ }^{2-} \\
\mu \mathrm{Eqm}^{-2}\end{array}$ & $\begin{array}{c}\mathrm{NO}_{3}^{-} \\
\mu \mathrm{Eqm}^{-2}\end{array}$ & 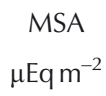 \\
\hline Annual mean & 176 & 31.8 & 3.33 & 0.22 & 1.28 & 1.93 & 4.86 & 12.78 & 8.44 & 0.14 \\
\hline 'Winter-to-summer' mean & 97 & 17.3 & 2.26 & 0.16 & 0.87 & 1.46 & 3.32 & 7.62 & 5.35 & 0.06 \\
\hline 2007 winter to 2008 summer & 88 & 16.3 & 4.04 & 0.23 & 1.20 & 1.65 & 5.01 & 6.13 & 6.57 & 0.05 \\
\hline 2006 winter to 2007 summer & 97 & 18.2 & 1.11 & 0.11 & 0.63 & 1.13 & 2.20 & 7.61 & 4.73 & 0.07 \\
\hline 2005 winter to 2006 summer & 107 & 17.4 & 1.63 & 0.14 & 0.76 & 1.61 & 2.74 & 9.12 & 4.74 & 0.07 \\
\hline 'Summer-to-winter' mean & 78 & 14.5 & 1.07 & 0.05 & 0.41 & 0.47 & 1.54 & 5.16 & 3.09 & 0.07 \\
\hline 2008 summer to 2008 winter & 68 & 11.3 & 0.60 & 0.02 & 0.25 & 0.30 & 0.80 & 3.69 & 2.58 & 0.06 \\
\hline 2007 summer to 2007 winter & 70 & 13.2 & 1.00 & 0.06 & 0.40 & 0.50 & 1.50 & 4.57 & 3.04 & 0.09 \\
\hline 2006 summer to 2006 winter & 96 & 19.0 & 1.62 & 0.08 & 0.58 & 0.60 & 2.33 & 7.23 & 3.65 & 0.06 \\
\hline
\end{tabular}

The two major final products of the DMS oxidation processes are $\mathrm{nsSO}_{4}{ }^{2-}$ and MSA. Different timings of $\mathrm{nsSSO}_{4}{ }^{2-}$ and MSA peaks could imply that DMS is not a predominant source of $\mathrm{nsSSO}_{4}{ }^{2-}$ at NEEM. A closer look at the $\mathrm{nsSSO}_{4}{ }^{2-}$ seasonality, however, might indicate that the falling leg of the nssSO ${ }_{4}{ }^{2-}$ peak in spring overlapped at least part of the MSA peak in spring, and that a $\mathrm{nsSOO}_{4}{ }^{2-}$ peak in summer to autumn, which was generally very small except in 2007, was seen in the rising leg of the MSA peak in summer to autumn. Hence, we cannot yet rule out the possibility that $\mathrm{nsSSO}_{4}{ }^{2-}$ originated from DMS might have shared a noticeable fraction of $\mathrm{nsSSO}_{4}{ }^{2-}$ in spring and late summer to autumn. We plot the $\mathrm{MSA}_{\mathrm{nssSO}}{ }^{2-}$ ratios in Figure 5. The ratio showed a major peak in late summer to autumn, with a minor peak or shoulder in spring. As our study covers only 4 years, and as our pit data are subject to noise, we cannot conclude that the minor peaks or shoulders in $\mathrm{nssSO}_{4}{ }^{2-}, \mathrm{MSA}$ and $\mathrm{MSA} / \mathrm{nssSO}_{4}{ }^{2-}$ occurred regularly over multiple years. In addition, we cannot yet draw a firm conclusion about the source apportionment of nssSO ${ }_{4}{ }^{2-}$. Accordingly, interpretation of the seasonality of $\mathrm{MSA} / \mathrm{nsSSO}_{4}{ }^{2-}$ is rather complex. Studies using sulfur isotopes and those covering longer periods are needed.

\section{Surface mass balance}

We calculated the annual surface mass balance for the years 2006-08 at NEEM (Table 1). Each year was defined using the profile of the stable-isotope ratio, so that the border between the two adjacent years was located at the layer with a stableisotope minimum. To examine the seasonal distribution of snow accumulation, we divided one year into two parts: one representing the first half of the year (stable-isotope minimum to maximum) and the other representing the second half of the year (stable-isotope maximum to minimum). Here we define the former as 'winter to summer' (winter-springsummer) and the latter as 'summer to winter' (summerautumn-winter). The annual mean surface mass balance during the 3 years was $176 \mathrm{~mm}$ w.e., which is substantially less than the $0.26 \mathrm{~m} \mathrm{a}^{-1}$ estimated by Buchardt and DahlJensen (2008). The surface mass balance in 2006 (2005 winter to 2006 winter) was $203 \mathrm{~mm}$, which was the maximum of the three years. On the other hand, the surface mass balance in 2008 (2007 winter to 2008 winter) was less than in 2006 by $\sim 50 \mathrm{~mm}$. We found that the year-to-year variability of surface mass balance at NEEM was $>20 \%$. The snow depositions during the winter-to-summer and summerto-winter seasons were 98 and $78 \mathrm{~mm}$, respectively. Snow deposition during the winter-to-summer half of the year was greater than that during the other half of the year by 10 $20 \mathrm{~mm}$ for all three years. As these findings are based only on the past 3 years, they need to be further investigated by examining both shallow and deep ice cores drilled at NEEM.

The depositions of $\mathrm{Na}^{+}, \mathrm{K}^{+}, \mathrm{Mg}^{2+}, \mathrm{Ca}^{2+}, \mathrm{Cl}^{-}, \mathrm{NO}_{3}{ }^{-}$and $\mathrm{SO}_{4}{ }^{2-}$ showed large seasonal differences (Table 1). The 2007 winter to 2008 summer season had substantially greater depositions of $\mathrm{Na}^{+}, \mathrm{K}^{+}, \mathrm{Mg}^{2+}$ and $\mathrm{Cl}^{-}$than any other seasons. During this season, deposition of these ions was $>1.5$ times the seasonal mean, which is due to the high peak around $0.6 \mathrm{~m}$ depth. Separation of non-sea-salt and sea-salt fractions (Fig. 4) indicates that the sea salt, not dust components, showed a pronounced peak in early spring of 2008. In general, all the ions but MSA show greater deposition during winter to summer than summer to winter. For instance, average depositions of major sea-salt components $\mathrm{Na}^{+}, \mathrm{Cl}^{-}$ and $\mathrm{Mg}^{2+}$ during winter to summer were about two times greater than those during the summer to winter. $\mathrm{Ca}^{2+}$ showed an even greater seasonal difference, which was more than threefold. These seasonal differences were greater than those observed for $\mathrm{H}_{2} \mathrm{O}$. Depositions of $\mathrm{K}^{+}, \mathrm{NO}_{3}{ }^{-}$and $\mathrm{SO}_{4}{ }^{2-}$ were also greater during the winter to summer. Among all the ionic species, only MSA showed greater deposition in summer to winter. This study demonstrated that the depositions of most chemical components studied were highest in the winter-to-summer half of the year at NEEM.

\section{CONCLUSIONS}

We conducted a pit study in July 2009 at NEEM. Highresolution sampling at every $0.03 \mathrm{~m}$ allowed for identification of detailed seasonal chemical characteristics in the surface snow/firn. Distinct seasonal variations in the stable isotopes of water $\left(\delta^{18} \mathrm{O}, \delta \mathrm{D}\right)$ were observed. Concentrations of $\mathrm{Na}^{+}, \mathrm{Mg}^{2+}$ and $\mathrm{Cl}^{-}$peaked in winter to early spring. Of the latter two ions, only the fractions originated from sea-salt aerosols peaked in this season. Concentrations of $\mathrm{nssCa}^{2+}$ and $\mathrm{nssMg}^{2+}$, which were of dust origin, peaked in late winter to spring, following the peak of $\mathrm{Na}^{+}, \mathrm{Mg}^{2+}$ and $\mathrm{Cl}^{-}$. Concentrations of $\mathrm{K}^{+}$showed a peak in winter to spring, and possibly a secondary peak in summer. The summer peak of $\mathrm{K}^{+}$, if this does exist, may have been caused by increased biomass burning in summer (Whitlow and others, 1992), whereas the origin of the winter-to-spring peak is not clear. Concentrations of $\mathrm{NO}_{3}{ }^{-}$showed double peaks, one in 
summer and the other in winter to spring, whereas those of $\mathrm{SO}_{4}{ }^{2-}$ peaked in winter to spring. The winter-to-spring concentrations of $\mathrm{NO}_{3}{ }^{-}$and $\mathrm{SO}_{4}{ }^{2-}$ were likely influenced by anthropogenic inputs. Concentrations of MSA seems to have shown double peaks, one in spring and the other in late summer to autumn. While the seasonality of MSA seems to reflect the seasonality of emissions, oxidation and transport processes of DMS, the sulfur budget at NEEM is not yet clearly understood. Further investigations using nitrogen and sulfur isotopes as well as analyses of ice cores covering the pre-industrial period will be necessary. Nevertheless, seasonal variations of ion concentrations and also those of the $\mathrm{Cl}^{-} / \mathrm{Na}^{+}$ratio, which displayed a distinct summer peak, can be used to absolutely date the NEEM deep ice core by annual-layer counting.

The annual mean surface mass balance during 2006-08 was $176 \mathrm{~mm}$ w.e. The snow deposition during the winter-tosummer half of the year exceeded that in the summerto-winter half of the year by $10-20 \mathrm{~mm}$ for all three years. The deposition of $\mathrm{Na}^{+}, \mathrm{K}^{+}, \mathrm{Mg}^{2+}, \mathrm{Ca}^{2+}, \mathrm{Cl}^{-}, \mathrm{NO}_{3}{ }^{-}$and $\mathrm{SO}_{4}{ }^{2-}$ was also greater in the first half of the year (winter to summer) than the latter half (summer to winter), and showed larger seasonal differences than those of $\mathrm{H}_{2} \mathrm{O}$. The information about present-day surface mass balance, and depositions of ions and their variability will provide the basis to interpret data from the NEEM deep ice core.

\section{ACKNOWLEDGEMENTS}

NEEM is directed and organized by the Center for Ice and Climate at the Niels Bohr Institute and the US National Science Foundation (NSF) Office of Polar Programs (OPP). It is supported by funding agencies and institutions in Belgium (FNRS-CFB and FWO), Canada (NRCan/GSC), China (CAS), Denmark (FIST), France (IPEV, CNRS/INSU, CEA and ANR), Germany (AWI), Iceland (Rannls), Japan (NIPR), Korea (KOPRI), The Netherlands (NWO/ALW), Sweden (VR), Switzerland (SNF), the UK (NERC) and the USA (US NSF OPP). This work was also supported by the Advance Project of NIPR 'Approaching Earth System Dynamics through the Past Polar Changes: Reconstruction of Quaternary Polar Environmental and Global Atmospheric Changes with High Accuracy and High Temporal Resolution', and Grants-in-Aid for Scientific Research 21710017 and 22221002 of the Japan Society for the Promotion of Science. The support from NEEM field members and the laboratory technicians at NIPR is appreciated.

\section{REFERENCES}

Albert, M.R. and E. Shultz. 2002. Snow and firn properties and airsnow transport processes at Summit, Greenland. Atmos. Environ., 36(15-16), 2789-2797.

Barbante, C. and 7 others. 2003. Seasonal variations of heavy metals in central Greenland snow deposited from 1991 to 1995. J. Environ. Monitor., 5(2), 328-335.

Barrie, L.A. and M.J. Barrie. 1990. Chemical components of lower tropospheric aerosols in the High Arctic: six years of observations. J. Atmos. Chem., 11(3), 211-226.

Beer, J. and 15 others. 1991. Seasonal variations in the concentrations of ${ }^{10} \mathrm{Be}, \mathrm{Cl}^{-}, \mathrm{NO}_{3}{ }^{-}, \mathrm{SO}_{4}{ }^{2-}, \mathrm{H}_{2} \mathrm{O}_{2},{ }^{210} \mathrm{~Pb},{ }^{3} \mathrm{H}$ mineral dust and $\delta^{18} \mathrm{O}$ in Greenland snow. Atmos. Environ. A, 25(5-6), 899-904.
Bigler, M. and 6 others. 2002. Sulphate record from a northeast Greenland ice core over the last 1200 years based on continuous flow analysis. Ann. Glaciol., 35, 250-256.

Buchardt, S.L. and D. Dahl-Jensen. 2008. At what depth is the Eemian layer expected to be found at NEEM? Ann. Glaciol., 48, 100-102.

Candelone, J.P., J.L. Jaffrezo, S. Hong, C.I. Davidson and C.F. Boutron. 1996. Seasonal variations in heavy metals concentrations in present day Greenland snow. Sci. Total Environ., 193(2), 101-110.

Dansgaard, W. and 6 others. 1982. A new Greenland deep ice core. Science, 218(4579), 1273-1277.

Dibb, J.E., S.I. Whitlow and M. Arsenault. 2007. Seasonal variations in the soluble ion content of snow at Summit, Greenland: constraints from three years of daily surface snow samples. Atmos. Environ., 41(24), 5007-5019.

Drab, E., A. Gaudichet, J.L. Jaffrezo and J.L. Colin. 2002. Mineral particles content in recent snow at Summit (Greenland). Atmos. Environ., 36(34), 5365-5376.

EPICA Community Members. 2004. Eight glacial cycles from an Antarctic ice core. Nature, 429(6992), 623-628.

EPICA Community Members. 2006. One-to-one coupling of glacial climate variability in Greenland and Antarctica. Nature, 444(7116), 195-198.

Finkel, R.C., C.C. Langway, Jr and H.B. Clausen. 1986. Changes in precipitation chemistry at Dye 3, Greenland. J. Geophys. Res., 91(D9), 9849-9855.

Fischer, H., D. Wagenbach and J. Kipfstuhl. 1998. Sulfate and nitrate firn concentrations on the Greenland ice sheet. 1. Largescale geographical deposition changes. J. Geophys. Res., 103(D17), 21,927-21,934.

Goto-Azuma, K., R.M. Koerner, M. Nakawo and A. Kudo. 1997. Snow chemistry of Agassiz Ice Cap, Ellesmere Island, Northwest Territories, Canada. J. Glaciol., 43(144), 199-206.

Goto-Azuma, K., R.M. Koerner, M.N. Demuth and O. Watanabe. 2006. Seasonal and spatial variations of snow chemistry on Mount Logan, Yukon, Canada. Ann. Glaciol., 43, 177-186.

Greenland Ice-Core Project (GRIP) Members. 1993. Climate instability during the last interglacial period recorded in the GRIP ice core. Nature, 364(6434), 203-207.

Grootes, P.M., M. Stuiver, J.W.C. White, S. Johnsen and J. Jouzel. 1993. Comparison of oxygen isotope records from the GISP2 and GRIP Greenland ice cores. Nature, 366(6455), 552-554.

Hastings, M.G., E.J. Steig and D.M. Sigman. 2004. Seasonal variations in $\mathrm{N}$ and $\mathrm{O}$ isotopes of nitrate in snow at Summit, Greenland: implications for the study of nitrate in snow and ice cores. J. Geophys. Res., 109(D20), D20306. (10.1029/ 2004JD004991.)

Jaffrezo, J.L., C.I. Davidson, M. Legrand and J.E. Dibb. 1994. Sulfate and MSA in the air and snow on the Greenland ice sheet. J. Geophys. Res., 99(D1), 1241-1253.

Johnsen, S.J., W. Dansgaard and J.W.C. White. 1989. The origin of Arctic precipitation under present and glacial conditions. Tellus B, 41(4), 452-468.

Legrand, M. 1997. Ice-core records of atmospheric sulfur. Philos. Trans. R. Soc. London, Ser. B, 352(1350), 241-250.

Legrand, M.R. and R.J. Delmas. 1988. Formation of $\mathrm{HCl}$ in the Antarctic atmosphere. J. Geophys. Res., 93(D6), 7153-7168.

Legrand, M. and P. Mayewski. 1997. Glaciochemistry of polar ice cores: a review. Rev. Geophys., 35(3), 219-243.

Legrand, M., M. De Angelis, H. Cachier and A. Gaudichet. 1995. Boreal biomass burning over the last 80 years recorded in a Summit-Greenland ice core. In Delmas, R.J., ed. Ice core studies of global biogeochemical cycles. Berlin, etc., SpringerVerlag, 347-360. (NATO ASI Series I: Global Environmental Change 30.)

Legrand, M., S. Preunkert, D. Wagenbach and H. Fischer. 2002. Seasonally resolved Alpine and Greenland ice core records of 
anthropogenic $\mathrm{HCl}$ emissions over the 20th century. J. Geophys. Res., 107(D12), 4139. (10.1029/2001JD001165.)

Li, S.-M., L.A. Barrie and A. Sirois. 1993a. Biogenic sulfur aerosol in the arctic troposphere: 2. Trends and seasonal variations. J. Geophys. Res., 98(D11), 20,623-20,632.

Li, S.-M., L.A. Barrie, R.W. Talbot, R.C. Hariss, C.I. Davidson and J.L. Jaffrezo. 1993b. Seasonal and geographic variations of methanesulfonic acid in the Arctic troposphere. Atmos. Environ., 27A(17-18), 3011-3024.

Mann, J.L., C.A. Shuman, W.R. Kelly and K.J. Kreutz. 2008. Seasonal $\delta^{34} S$ variations in two high elevation snow pits measured by ${ }^{33} \mathrm{~S}^{36} \mathrm{~S}$ double spike thermal ionization mass spectrometry. Geochim. Cosmochim. Acta, 72(15), 3907-3927.

Mosher, B.W., P. Winkler and J.L. Jaffrezo. 1993. Seasonal aerosol chemistry at Dye 3, Greenland. Atmos. Environ. A, 27(17-18), $2761-2772$

Motoyama, H. and 9 others. 2001. Regional characteristics of chemical constituents in surface snow, Arctic cryosphere. Polar Meteorol. Glaciol., 15, 55-60.

Norman, A.L. and 6 others. 1999. Sources of aerosol sulphate at Alert: apportionment using stable isotopes. J. Geophys. Res., 104(D9), 11,619-11,631.

North Greenland Ice Core Project (NorthGRIP) Members. 2004. High-resolution record of Northern Hemisphere climate extending into the last interglacial period. Nature, 431(7005), 147-151.
Nriagu, J.O., R.D. Coker and L.A. Barrie. 1991. Origin of sulphur in Canadian Arctic haze from isotope measurements. Nature, 349(6305), 142-145.

Petit, J.R. and 18 others. 1999. Climate and atmospheric history of the past 420,000 years from the Vostok ice core, Antarctica. Nature, 399(6735), 429-436.

Steffensen, J.P. 1985. Microparticles in snow from the South Greenland ice sheet. Tellus, 37B(4-5), 286-295.

Steffensen, J.P. 1988. Analysis of the seasonal variation in dust, $\mathrm{Cl}^{-}$, $\mathrm{NO}_{3}{ }^{-}$and $\mathrm{SO}_{4}{ }^{2-}$ in two central Greenland firn cores. Ann. Glaciol., 10, 171-177.

Svensson, A. and 13 others. 2008. A 60000 year Greenland stratigraphic ice core chronology. Climate Past, 4, 47-57.

Uemura, R. 2007. Studies on the reconstruction of past temperature changes from stable isotopes of water: records of millennialscale climate change from polar ice cores. Quat. Res. (Japan), 46(2), 147-164. [In Japanese with English summary.]

Uemura, R., N. Yoshida, N. Kurita, M. Nakawo and O. Watanabe. 2004. An observation-based method for reconstructing ocean surface changes using a 340,000-year deuterium excess record from the Dome Fuji ice core, Antarctica. Geophys. Res. Lett., 31(13), L13216. (10.1029/2004GL019954.)

Whitlow, S., P.A. Mayewski and J.E. Dibb. 1992. A comparison of major chemical species seasonal concentration and accumulation at the South Pole and Summit, Greenland. Atmos. Environ., 26A(11), 2045-2054. 